\title{
Content Analysis of Linguistic Sexism in Jordanian English as a Foreign Language (EFL) Textbooks
}

\author{
Adnan Bataineh
}




\begin{abstract}
Linguistic sexism is still prevalent in many school textbooks. This study aims at performing a content analysis of linguistic sexism in nine Jordanian English as a Foreign Language (EFL) textbooks. The purpose of this study was to examine whether or not linguistic sexism is inculcated in these textbooks. To examine linguistic sexism, the study investigated linguistic sexism implied by images, photographs, illustrations, pictures, and texts found in Jordanian EFL textbooks. The study investigated the presence and number of masculine and feminine pronouns and adjectives. The results showed that Jordanian EFL textbooks contained substantial linguistic sexism. Moreover, quantitative data showed that males' presence was superior to females' presence. In other words, the number of feminine pronouns and adjectives used in images, photographs, pictures, and illustrations was significantly inferior to males'. Finally, the study showed that the adjectives used in these textbooks are stereotypical of males and females. In sum, the Jordanian EFL textbooks contained significant linguistic sexism.

Key words: linguistic sexism, stereotypes, textbooks, English language, gender.
\end{abstract}




\section{Introduction}

Linguistic sexism in textbooks is central to education. This is a study of linguistic sexism in Jordanian English as a Foreign Language (EFL) textbooks. The focus is on overt and covert messages implied in male and female text and images in terms of gender. Many recent studies have shown that linguistic sexism is still deeply-rooted in school textbooks (Abdul Hamid, 2008; Al-Ramahi, 2013; Dominguez, 2003; Esen; 2007, Ghorbani, 2009; Hamdan, 2008; Jenjekwa et al, 2013; Pattalung, 2008; \& Yasin et al., 2012). This study is designed to explore whether linguistic sexism still exists in Jordanian EFL textbooks. The analysis will include an examination of linguistic sexism (the use of androcentric language, Gersha, 1997) in these textbooks.

\section{Research Questions}

The main research questions are

1- Does linguistic sexism exist in Jordanian EFL textbooks?

2- If it exists, what form does it take?

\section{Rationale}

Recent studies from different parts of the world have indicated that linguistic sexism (gender bias) exists in school textbooks (Al-Ramahi, 2013; Ghorbani, 2009; Jenjekwa et al. (2013); \&Yasin et al., 2012). There have been few studies on linguistic sexism in Jordanian textbooks other than studies by Al-Rahami, 2013. Gender bias may lead to stereotyping female as well as male learners. This study attempts to identify whether or not linguistic sexism (gender bias) exists in Jordanian EFL curricula and textbooks. Researchers such as Al-Ramahi found that Jordanian nursery rhymes textbooks are full of sexist language. If Jordanian EFL textbooks became apparent to be full of sexist language, endeavors should be put forth to deal with this persisting problem. It is worth mentioning to note that the Jordanian Ministry of Education regularly puts an effort to improve the standards and design of Jordanian EFL textbooks. This study may help the Jordanian Ministry of Education better understand the need for any further improvement in the design of Jordanian EFL textbooks, if it exists.

\section{Literature Review}

Linguistic sexism in textbooks and curricular materials is a form of gender inequity.

Holmes (1996) defined sexism as"... the ways in which language conveys negative attitudes to women." 
(as cited in Dominguez, 2003). Gershaw (1997) defined sexism as the use of androcentric language, that is, language that is centered around the male (andro-) portion of the population.

He argues that this androcentric bias leads to linguistic sexism. Gershaw stated that the use of terms such as man or mankind to refer to humankind excludes women. Gershaw supported his argument with statistics that show women outnumber men in American society. Gershaw warned that linguistic sexism is ingrained in people's language to such an extent that people sometimes are not conscious of using linguistically sexist expressions or do not recognize when others use such expressions.

The use of generic masculine pronouns to refer to both sexes is a common practice among people. Jenjekwa et al. (2013) conducted a study of two examination papers of Zimbabwe Schools Examinations Council (ZIMSEC). It revealed that these exam papers are masculine in nature and talk about "males' adventurism as well as male intellectual and physical prowess". Yasin et al. (2012) conducted a study on Linguistic Sexism in Qatari Primary Mathematics Textbooks. The study used qualitative and quantitative approaches to analyze the texts. The study revealed that imported texts contain linguistic sexism (males' dominance), while Qatari textbooks showed females' dominance. Moreover, Ghorbani's (2009) study examined sexism in three ESL/EFL textbooks series currently used in Iranian language institutes. The study showed that such textbooks are still full of sexist concepts and attitudes. Gershaw (1997) stated that many people usually assume that the use of his refers to both males and females in a sentence such as: the student has finished his homework. It is recommended to use the plural form their to refer to both sexes: the students have finished their homework. In other words, the use of language in classrooms and textbooks should be inclusive. Authors and teachers should use inclusive language that refers to both sexes instead of one sex. This practice is more equitable to both males and females. Pattalung's (2008) PhD dissertation included a study of the types of sexist language that appear in fifteen ESL Thai textbooks. He stated that "the results of this study show that sexist language is present in the textbooks and that the textbooks contain content that promotes sexist assumptions concerning gender roles." His study also revealed that "two hundred fifty instances of words that indicate that men are the standard by which people are to be judged were found in the textbooks, particularly in generic pronouns such as "he," "his" and "him" to refer to everyone." Another study by Esen (2007) investigated the new books recommended by the "curriculum reform" in Turkey.

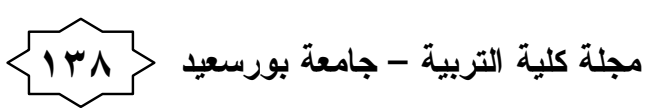

$$
\begin{aligned}
& \text { العدد الخامس عشر - يناير \& ا ب rم }
\end{aligned}
$$


The "curriculum reform" is one of the demands Turkey has to meet to join EU. The study found that these textbooks increase gender bias and gender segregation.

Some studies focused on the analysis of pronouns, verbs, adjectives, and nouns used in textbooks. Al-Ramahi's (2013) study of nursery rhymes used in Jordan revealed that the verbs used with females in such rhymes "reinforced the negative features of female stereotypes". The verbs used included could never agree, could not speak plain, and cried Carroll and Kowitz's (1994) study of many EFL/ESL textbooks revealed that male pronouns area more common than female pronouns. They also found that certain adjectives collocated with men such as important, famous, rich, lazy, afraid, pleased, and happy. Moreover, adjectives such as angry collocated more strongly with women/women than men/men. In other words, adjectives such as angry were used more often in situations that involved women interacting with other women than with men interacting with other men. The most important used to describe adjectives women were: busy, beautiful, pretty, and tall. These findings reflect blatant sexism (Carroll \& Kowitz, 1994 as cited in Renner, 1997). Yasin's et al. (2012) study on Linguistic Sexism in Qatari Primary Mathematics Textbooks concluded that the males pronoun 'he' is more noticeable than "she" and that 'he' occurred more often that the female pronoun 'she'. However, the study revealed that the occurrence of pronoun 'her" is much higher than the occurrence of 'his' in foreign textbooks. Another study by Abdul Hamid et al. (2008) investigated linguistic sexism and gender role stereotyping in Malaysian English language textbooks. They investigated the use of male and female pronouns: He, She, Hi, Her, Himself, and Herself. The preliminary findings of their study generally show that males' pronouns have "significantly higher occurrence than females'.

A similar study included an analysis of adjectives, verbs, adverbs, and nouns in textbooks. Rifkin (1998) investigated the number and kinds of verbs, adjectives, and adverbs used with male and female subjects. He found, for example, that in chapter 11 of a Russian language textbook, males were twice as likely to "forget" as females and were likely to "read" than females. He also found that adjectives used to refer to males included "interesting", "surprising", and "favorite", while adjectives used to refer to females included "pretty" and "beautiful." Rifkin's (1998) study revealed that the verb "to know" is used more than twice as often with males as with females.

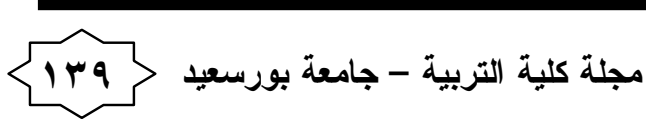

$$
\begin{aligned}
& \text { العدد الخامس عشر - يناير \& ا بـ م }
\end{aligned}
$$




\section{Method}

I conducted content analysis of nine Jordanian EFL school textbooks. According to Kohlbacher (2006)), content analysis is divided into two types: classical (quantitative) and qualitative content analysis. Titscher et al. (2000) defined classical content analysis as "the longest established method of text analysis among the set of empirical methods of social investigation" (as cited in Kohlbacher, 2006). Patton (2004) defined qualitative content analysis as "“"a research method for the subjective interpretation of the content of text data through the systematic classification process of coding and identifying themes or patterns." (as cited by Zhang, 2009). It is vital that researchers engage qualitative and quantitative methods to offer an objective analysis of the texts at hand.

\section{Measures}

In order to analyze the nine textbooks in my sample, I will use categories of analysis that $I$ have drawn from previous research studies. Moreover I devised some categories to investigate gender equity in Jordanian EFL school textbooks.

\section{Linguistic Sexism}

I identified linguistic sexism through the study of pronouns and adjectives in texts. I identified the total number of masculine pronouns (he, him, his) and feminine pronouns (she, her) throughout the textbooks. I also identified the number of masculine and feminine pronouns in each textbook to explore discrepancies among these textbooks. As for adjectives, I explored the total number of adjectives associated with males and females in these textbooks, along with detailed information about the number of adjectives in each textbook. Moreover, I studied these adjectives to investigate if they are stereotypical of males and females (e.g., males are famous, while females are young).

\section{Findings}

Content analysis was used to answer the two research questions to identify linguistic sexism in Jordanian EFL textbooks.

\section{Linguistic Sexism}

The analysis of pronouns and adjectives showed that linguistic sexism is a prevalent fact in Jordanian EFL textbooks. As for pronouns, statistics showed that there is blatant and overt sexism. The number of male 


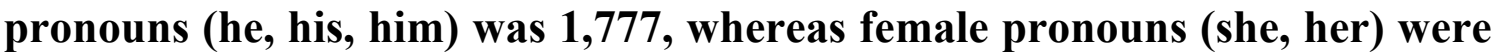
491.

The discrepancy in number of pronouns and their distribution in each textbook is provided in Table 1 . These results confirmed previous studies that textbooks and other curricular materials are linguistically sexist. In other words, female presence was minimal. Statistics also showed that the highest number of minimal pronouns in comparison with female pronouns was found in Reader 4 for Eighth Grade. Male pronouns were 314, while female pronouns were only 7 . It is also worth mentioning that Workbook 4 has almost an equal number of male and female pronouns (male $=129$ and female $=110$ ). With the exception of Workbook 4, the other eight Jordanian EFL textbooks are all about male presence.

Table 1.

Pronoun Distribution in Jordanian EFL Textbooks

\begin{tabular}{|c|c|c|}
\hline Textbook & Male & Female \\
\hline Reader 3 & 102 & 17 \\
\hline Reader 4 & 314 & 7 \\
\hline Reader 6 & 334 & 46 \\
\hline Students' Book 4 & 326 & 120 \\
\hline Students' Book 5 & 217 & 39 \\
\hline Students' Book 6 & 145 & 61 \\
\hline Workbook 3 & 113 & 47 \\
\hline Workbook 4 & 129 & 110 \\
\hline Workbook 5 & 97 & 44 \\
\hline Total & 1777 & 491 \\
\hline
\end{tabular}

Moreover, the analysis of adjectives revealed that adjectives collocated with males were much more prevalent than those collocated with females. The total number of adjectives associated with males was 388, and for females was 73. The total numbers of adjectives associated with males and females in each textbook are provided in Table 2. For example, the adjective famous was used with males 80 times, while it was used only 3 times with females. The analysis showed clearly that major discrepancies occurred in the Readers. Reader 4 contained 98 adjectives associated with males, and only 2 adjectives were associated with females.

Furthermore, there were differences in the types of adjectives associated with males and females. Adjectives such as great, old, young and some superlatives such as best and first were also more frequently associated with males than with females. Other male adjectives included clever, successful, brave, rich, lazy, religious, holy, powerful, heart-broken, and soft-hearted. Although adjectives associated with females were mainly young, old, good, there were some other adjectives such as famous, brilliant, and clever that were used, although not as often as with men. In sum, 
adjectives used in these textbooks were generally stereotypical of males and females.

Table 2.

Adjectives Associated with Males and Females

\begin{tabular}{|c|c|c|}
\hline Textbook & Male & Female \\
\hline Reader 3 & 25 & 16 \\
\hline Reader 4 & 98 & 2 \\
\hline Reader 6 & 92 & 5 \\
\hline Students' Book 4 & 44 & 14 \\
\hline Students' Book 5 & 36 & 11 \\
\hline Students' Book 6 & 18 & 8 \\
\hline Workbook 3 & 22 & 4 \\
\hline Workbook 4 & 17 & 9 \\
\hline Workbook 5 & 36 & 11 \\
\hline Total & 388 & 80 \\
\hline
\end{tabular}

\section{Limitations}

It is worth mentioning that this study included only nine Jordanian EFL textbooks. In other words, the findings of this study may or may not be applicable to all Jordanian EFL textbooks. It is vital to have more research done on Jordanian EFL textbooks to have more conclusive results.

\section{Conclusion}

Findings of this study confirmed previous studies on linguistic sexism in textbooks. These results show that major instances of sexist language are still prevailing in the Jordanian EFL textbooks. Feminine pronouns, nous, and adjectives were quantitatively and qualitatively less frequent and visible than males' in these texts. In other words, the number of feminine pronouns, adjectives, and nouns was lower than the number of males'. Finally, the study demonstrated that images and texts covertly and overtly contained flagrant linguistic sexism (gender bias). 


\section{References}

1. Abdul Hamid, B., D., Yasin, M., S., Abu Bakar, k., Keong, Y., C., \& Jalauddin, A. (2008). Retrieved December, 15, 2013, from http://www.ukm.my/ppbl/Gema/GEMA\%20vol\%208\%20(2)\%202008/page45_78. pdf

2. Al Ramahi, R., A. (2013). Sexist Bias Manifested in the Language of Nursery Rhymes: Analysis of Sexist Linguistic Features. Retrieved January, 15, 2014, from http://eujournal.org/index.php/esj/article/view/1922

3. Dominguez, L. ( 2003). Gender Textbook Evaluation. Retrieved January, 01, 2014, from http://www.birmingham.ac.uk/documents/collegeartslaw/cels/essays/sociolinguistics/dominguez5.pdf

4. Esen, Y. ( 2007). Sexism in School Textbooks Prepared under Education Reform in Turkey. Retrieved January, 10, 2014, from http://www.jceps.com/PDFs/05-2-15.pdf

5. Gershaw, A. D. (1997). Our androcentric language. Retrieved August, 20, 2013, from

http://virgil.azwestern.edu/ dag/lol/Androcentric.htm

6. Ghorbani, L. (2009). An investigation of the Manifestation of Sexism in EFL/ESL Textbboks. Retrieved September, 20, 2013, from http://files.eric.ed.gov/fulltext/ED505434.pdf

7. Hamdan, S. M. T. (2008). Analyzing Aspects of Gender in English Language Jordanian Basic Stage Curriculum from A Socio-Cultural Perspective. Retrieved December, 05, 2013, from http://asian-efljournal.com/Thesis/Thesis-Hamdan.pdf

8. Jenjekwa, V., Ester, R., \& Julius, R. (2013). Vestiges of Sexism and Gender Stereotyping: ZIMSEC Ordinary Level English Language Examinations from 2007 to 2012. Retrieved January, 05, 2014, from http://www.ijern.com/journal/June-2013/34.pdf

9. Kohlbacher, F. (2006). The Use of Qualitative Content Analysis in Case Study Research. Retrieved February, 01, 2014, from http://www.qualitativeresearch.net/index.php/fqs/article/\%20view/75/153January\%202006

10. Pattalung, P., N. (2008). An Analysis of Sexist Language in ESL Textbooks by Thai Authors Used in Thailand. Retrieved January, 07, 2014, from

http://digital.library.unt.edu/ark:/67531/metadc9057/m2/1/high_res_d/dissertatio n.pdf

11. Renner. C.E. (1997). Women are "busy, tall and beautiful:" looking at sexism in EFL materials. Rome: National seminar "Mind the language." (ERIC Document Reproduction Service No. ED411670) 
12. Rifkin, B. (1998). Gender representation in foreign language textbooks: A case study of textbooks of Russian. The Modern Language Journal, 82 (2), 219-236.

13. Yasin, M. S. M, Abdul Hamid, B., Keong, Y. C., Othman, Z., \& Jaludin, A. (2012). Retrieved October, 03, 2013, from http://www.ukm.my/ppbl/Gema/GEMA\%20vol\%2012\%20(1)\%20Special\%20sec tion\%202012/pp_53_68.pdf

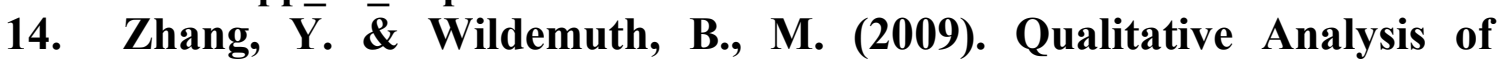 Content. Retrieved January, 03, 2014, from https://www.ischool.utexas.edu/ yanz/Content_analysis.pdf 